\title{
INTRODUCTION: THE LONG ROAD TO GLOBAL JUSTICE, PEACE, AND HUMANITY
}

Global justice, global peace, and global humanity are three central values and three objectives in global human affairs; they are three dimensions of the same human aspiration. The Confucian classic, the Daxue (Great Learning), outlines three Confucian ideals of the world: the manifestation of bright virtue(s), the renovation of the people, and the realization of the ultimate good; in the words of the text, "Ming ming de, qin [xin] min, zhi yi zhi shan." "In present idiom, the Confucian ideals become the realization of global justice (bright virtue), the realization of global peace (having a renovated world and people), and the realization of humanity (arriving at the utmost good).

Justice is one of the most enduring human values. Indeed, in the history of human civilization as we know, justice has been hailed as one of the most fundamental ethical and political values in the human ethos and occupied a powerful position in our moral, legal, and political rhetoric. "Justitia virtutum regina (Justice is the queen of virtues),"2 says a Latin proverb. Today, globalization and modernity bring radical changes in the world and call for global justice. Some philosophers resist the concept of global justice, especially global socioeconomic justice. Others disagree.

Global justice is an enduring idea in traditional Chinese philosophies. The Confucian classic, the Zhongyong (Doctrine of the Mean):

Zhong ye zhe, tian xia zhi da ben ye; he ye zhe, tian xia zhi da dao ye. Zhi zhong he, tian di wei yan, wanwu yu yan (Equilibrium is the great foundation of the world and harmony is its universal path. When equilibrium and harmony are realized to the highest degree, heaven and earth will attain their proper order and all things will flourish.). ${ }^{3}$

The Daxue also considers ping tian xia (global peace) to be part of the zhi shan (the ultimate good). In connection with peace, wars between or among nations should also be an object of the concern of global justice.

XUNWU CHEN, associate professor, Department of English, Classics, and Philosophy, University of Texas at San Antonio. Specialties: Chinese philosophy, Continental philosophy, and social/political philosophy. E-mail: xun.chen@utsa.edu

(C) 2007 Journal of Chinese Philosophy 
To sort out issues pertaining to global justice, peace, and humanity here, we should revisit the question of what justice is. Among Chinese philosophies, the concept of justice, or zhengyi, has four different meanings. In one sense, zhengyi connotes righteousness that stands straight, contrasted to what is crooked. Standing straight has a moral meaning: (i) What is just is right and fair to all concerned parties from their respective perspectives and can face scrutiny from different perspectives; and (ii) what is just is justified. Thus, the concept of justice invokes such principles as gongzheng (fair and justified), gongping (fair and impartial), zhongzheng (standing straight in the center), bu pian bu yi (not favoring any party), li (reasonableness), and $y i$ (fitness). In Chinese, all these terms connote not only fairness and righteousness, but also the meaning of standing straight.

In another sense, zhengyi means authentic and original righteousness that is not adulterated or compromised. The concept of justice brings to mind such ideas as daoyi, gongyi, and gongli. One thus says, "Tie jian dan daoyi" (Being firm and resolute in shouldering justice). The concept of daoyi connotes righteousness that is supreme, pure, and inviolable. Confucius urged us: Xing yi yi da dao (to practice righteousness to amplify the dao in society). ${ }^{4}$ Mencius spoke of the energy of justice or righteousness as "hao ran zhi qi (the vast and unyielding energy)" that fills and the universe and makes one stand straight in the universe. ${ }^{5}$ Xunzi also said, "Dao yi zhong ze qing wang gong (When one pays attentions to justice in terms of the daoyi, one will not value social ranks and prestige)."

In a further sense, zhengyi connotes rectified, justified, or verified truth, principle, meaning, significance, essence, and substance. Thus, Confucius and Confucians talk about zhengming (properly ordering names or institutions). He argued that to govern is to zheng (correcting, rectifying). Zhengyi (justice) refers to those fundamental principles of things that are rectified. Zhengming orders these ideals properly and makes them stand straight.

Finally, zhengyi also means authentic and legitimate truth, essence, and substance of something. To have justice of $\mathrm{X}$ is to understand the original and unadulterated essence and substance of X. By this token, we read such books entitled Kongzi Zhengyi (The True Essence and Substance of the Teachings of Confucius), Mengzi Zhengyi (The True Essence and Substance of the Teachings of Mencius), and so on.

Therefore, the concept of zhengyi (justice) brings home the idea of justice as setting things right and setting righteousness to stand straight. The four senses of zhengyi above together emphasize the concept of justice as righteousness that stands straight, that is grounded in truth, whose essence and substance is original and profound, and that brings acceptability and legitimacy to practices, insti- 
tutions, or a person's conduct. By this token, we can define global justice as setting global human affairs right and making righteousness stand straight in global human affairs.

This returns us back to the intrinsic connections among global justice, global peace, and global humanity. Global justice is concerned with global peace; setting global human affairs right implies bringing global peace and cooperation among nations and peoples in globe. Indeed, global peace among nations and peoples is one aspect of the realization of global justice. Without global justice, there can be no stable global peace. Without global peace, global justice is not yet established. Global justice brings and sustains global peace. Global peace realizes global justice. In the end, the matter at hand boils down to one concept: Just global peace among humanity, by humanity, and for humanity.

The current conflicts in the Middle East provide an illustrative example here. These conflicts indicate that the absence of peace destroys the normal conditions in which humanity can prosper as a value and a species in the Middle East. The absence of peace is an absence of justice, creating conditions undesirable to global justice as a whole and to regional justice in the Middle East in particular.

Some historical approaches to justice also provide illuminating insights into the relations that obtain among justice, peace, and humanity. Plato associated justice with two qualities of a state and an individual's soul: (i) the rule of reason or the rational; and (ii) internal and external harmony. Plato also argued that until justice is realized, there is no hope for humanity. In other words, for Plato, justice, peace (harmony), and humanity are three interrelated ideas: Humanity that does not live in justice has no hope because there can be no peace among human beings and there can be no cessation of conflicts and troubles for the human race; there can be no justice without the rule of human reason; peace can only be obtained and maintained if there is justice and peace only has value if it realizes justice; without peace among human beings, there can be no justice.

It is fair to say that there are many definitions of "justice" in globalization or global justice and there is disagreement about the meaning, value, and possibility of global peace today. However, the subjects of global justice and global peace are of great interest to the whole world right now because of the argument and growing awareness that the prosperity of humanity as a value and as a species today demands global justice and global peace; in other words, global justice and global peace are not demanded for the sake of practical interests or expedience, but for the sake of humanity. This, in turn, leads us to two interrelated questions: (i) What is an ideal world order in which 
there can be global justice, peace, and humanity? (ii) How can we achieve such an order in the world?

Jürgen Habermas' article in this volume leads the discussion of global justice, peace, and humanity in a suggestive manner. Habermas brings out the Kantian concept of a cosmopolitan order in an ideal model of "The World Republic" or minimal acceptable model of an international league of nations. In Kant's ideal, whether it is a "World Republic," or an international league of nations, there are international laws that define justice in international affairs and that regulate human affairs internationally, and, therefore, "a violation of justice at one place on the Earth is felt at all others." ${ }^{77}$ Kant's idea of a cosmopolitan order is one in which there is the rule of law-the rule of international law-reason and justice and in which humanity is the end, not a means.

Habermas defends this idea of cosmopolitan order and points out, "the idea of a cosmopolitan order first received a lasting embodiment with the foundation of the United Nations." ${ }^{8}$ For Habermas, the idea of a cosmopolitan order will become more substantial if there can be a legitimate political constitution for the pluralist world that we live in today. The question here is not only about what kind of constitution such a political constitution should be, but also about how should such a constitution be established and by whom. Habermas points out the radical changing international theater and explores the legitimation crisis of international laws and treaties as well as various approaches to resolve such a crisis.

Habermas' article again reminds us of the Confucian ideals of tian xia you dao (There are just rules and ways in the world) and tian xia wei gong (All in the world serve humanity and public good). For Confucians, there must be just rites and institutions to structure our social and public lives in order to bring social harmony to our lives; all in the world should recover a sense of our duty to humanity in general-yi ren wei ji ren (realization of humanity in the world as one's mission). With these two conditions, the world is in ping zhi (peace and order).

Simultaneously, Habermas' article raises a serious philosophical question: If global justice should be defined by a political constitution for the world, then what substantive ideas and values should this political constitution embody, how should such a political constitution be established, and by whom should such a political constitution be established? The question here is not about whose justice and which rationality. The question is: How is global justice possible? The question is further: How is it possible for a political constitution for the world to be legitimately justified and morally normative?

There are philosophers who propose either modification of the Kantian project or alternatives to such a project. Chung-ying Cheng's 
article applies a Kantian-Confucian concept to a cosmopolitan order. Such a cosmopolitan order differs from the Kantian one in some crucial aspects, though they share many common points. According to Cheng, the basis for the traditional Kantian cosmopolitan order consists of the principle of justice in terms of rights, and justice in terms of freedom of human reason. The cosmopolitan order that Cheng proposes is based on the principle of ren (humanity) - the identity principle, and the principle of $y i$ (righteousness) - the difference principle. But Cheng's Confucian cosmopolitan order is grounded not only in the principles of rights, but also in the principles of duty and social harmony as a great good and embodiment of justice. World peace is a crucial component for Cheng's ideal Confucian cosmopolitan order. With regard to the question of how we should arrive at global peace or world peace, while Habermas emphasizes the rule of law and international institutions, Cheng emphasizes the universal consciousness of ren (humanity) and yi (righteousness).

While Habermas and Cheng are concerned with what kind of cosmopolitan order the world should be and how a certain form of normative justice should be achieved, Josef Seifert examines the relation between justice and peace. Seifert explores the meaning of global peace and the conditions under which such peace can be achieved. According to Seifert, justice and peace are closely connected with one another. Most interestingly, Seifert outlines nine conditions for what he calls authentic peace, including authentic global peace: (1) commitment to truth; (2) acknowledging human dignity and an objective order of goods, justice, and human rights which our mind has to discover; (3) acknowledging various human limits within which alone justice and other values can be realized on this earth; (4) readiness to forgive and to grant pardon as condition of peace; (5) responding to the just order and other goods for the right motives; (6) applying the golden rule; (7) recognizing of the absolute good; (8) never committing intrinsic evil acts against others; and (9) abstaining from the false "absolute-ization" of peace. Conditions (6) and (8) overlap with the Confucian altruism that Cheng advocates. Condition (7) overlaps with what the Great Learning says, as mentioned at the beginning of this Introduction. Conditions (1) and (5) should remind us of the Confucian commitment to following the human dao.

Xunwu Chen's article examines the relation between the ideas of justice and humanity and puts forth a concept of justice as setting things right in accordance with the principles of human rights, human goods, and human bonds. Correspondingly, he proposes a concept of the third family of global justice: Global justice as setting global human affairs right in terms of human rights, human goods, and human bonds. According to Chen, global justice as setting global 
affairs right intersects with global justice as fairness in distribution of resources, wealth, international burdens, and democratic participation in international institutions such as the United Nations, and also intersects with corrective justice such as punishing those who commit international war crimes. However, global justice as setting global human affairs properly is identical neither with global distributive justice nor with global corrective justice; it is a distinctive class of justice in its own right. In the end, Chen wants to suggest that to develop global peace, the five Confucian norms, ren (humanity), $y i$ (righteousness), li (propriety), zhi (wisdom), and xin (trust), should be norms of conduct in international affairs.

Barbara Entlová's article shares common points with Xunwu Chen's article on global humanity and peace. Drawing remarkably from Václav Havel, Entlová firstly criticizes the faith in violence that has a long tradition in human history, rejecting the belief that radical, even fundamental, social changes can be achieved only through violence. Especially, she rejects the argument that the realization of a political blueprint should disregard human costs and the belief that for whatever human costs we pay now for the radical social changes that we introduce through violence, the struggle will pay off in future.

Accordingly, Entlová argues for global peace in terms of humanity: human values, human rights, and human dignity. She proposes two steps to achieve and preserve global peace and justice: The promotion of consciousness of humanity across the globe through education, and the development of intentional laws and institutions that emphasize humanity as the highest value.

One may read Entlová as advocating the Mohist idea of jian ai (universal love). This is not what she aims at. Her article indeed reminds us of the Daoist rejection of violence and force. But what she focuses on is the concept of universal humanity: universal human dignity and rights. She does not argue for indiscriminate compassion for all sentient beings. Instead, she points to the historical and present marginalization of the idea of humanity in our moral and political decisions. She points to the present bad habit of loving violence in international human affairs today.

The discussions in this volume also bring into light the relevance of the insights of traditional Chinese philosophical concepts such as tian xia da tong (making the world in a global harmony), xiu shen, qi jia, zhi guo, ping tian xia (cultivating oneself, creating family in harmonious order, developing a country accordingly, and achieving peace in the world), wu ji bi fan (extremity produces self-destruction), and so on. The concept of tian xia da tong reinforces our concept of the world as a global human community: It is enormous, but it is in the harmony because it is a community of common humanity. The concept of xiu 
shen, qi jia, zhi guo, ping tian xia leads us to appreciate the dialectical relations among peace within oneself, peace in a local community, peace in a state, and global peace. The concept of wu ji bi fan reminds us of the proper way to arrive at and sustain global peace.

The road to global justice, global peace, and global humanity is still long and uneven, but the prospect of global justice, peace, and humanity is bright. Our duty is heavy and our mission is challenging, but our hope should be prosperous in every effort we are making.

UNIVERSITY OF TEXAS AT SAN ANTONIO

San Antonio, Texas

\section{ENDNOTES}

I would like to express my deep gratitude to Dr. John Trowbridge, Dr. Linyu Gu, and other editors of Journal of Chinese Philosophy, who have input a great amount of editorial work into the early drafts of my articles as well as other articles of the special theme.

1. Yang Xiaoming, ed., Daxue (Great Learning), in Four Books and Five Classics, chap. 1, vol. 1 (Chengdu: Bashu Publishing House, 1996), 4.

2. H. L. Mencken, ed., A New Dictionary of Quotations (New York: Alfred A. Knopf, 1942), 628.

3. Yang Xiaoming, ed., Zhongyong (Doctrine of the Mean), in Four Books and Five Classics, chap. 1, vol. 1 (Chengdu: Bashu Publishing House, 1996), 35.

4. Analects 16.11, in Four Books and Five Classics (Chengdu: Bashu Publishing House, 1996), 378.

5. Mengzi (Mencius), 2A2, vol. 1, in Four Books and Five Classics (Chengdu: Bashu Publishing House, 1996), 550.

6. Xunzi, Xunzi (Beijing: People's Daily Publishing House, 1998), 18.

7. The quotation is from section III of Habermas' article in this volume.

8. See Habermas' article in this volume.

\section{Chinese Glossary}

\begin{tabular}{|c|c|c|c|}
\hline bu pian bu yi & 不偏不倚 & Kongzi Zhengyi & 《孔子正义》 \\
\hline daoyi & 道义 & li & 礼 \\
\hline dao yi zhong z & ng gong & li & 理 \\
\hline 道义重则车 & & Mengzi & 孟子 \\
\hline Daxue & 《大学》 & Mengzi Zhengyi & 《孟子正义》 \\
\hline gongli & 公理 & ming ming de, qin & min, zhi yu \\
\hline gongping & 公平 & zhi shan & \\
\hline ongyi & 公义 & 明明德，亲（ & 民，止于至言 \\
\hline ngzheng & 公正 & ping tian xia & 平天下 \\
\hline o ran zhi qi & 浩然之气 & ping zhi & 平治 \\
\hline $\mathrm{n}$ ai & 兼爱 & ren & \\
\hline
\end{tabular}




\begin{tabular}{|c|c|c|c|}
\hline tian xia da tong & 天下大同 & zhengming & 正名 \\
\hline tian xia wei gong & 天下为公 & zhengyi & 正义 \\
\hline tian xia you dao & 天下有道 & zhi & 智 \\
\hline tie jian dan daoyi & 铁肩担道义 & zhi shan & 至善 \\
\hline wu ji bi fan & 物极必反 & zhongzheng & 中正 \\
\hline xin & 信 & Zhongyong & 《中庸》 \\
\hline xinyi & 信义 & zhong ye zhe & da ben ye; \\
\hline xing yi yi da dao & 行义以达道 & \multirow{2}{*}{\multicolumn{2}{|c|}{$\begin{array}{l}\text { he ye zhe, tian xia zhi da dao ye. Zhi } \\
\text { zhong he, tian di wei yan, wanwu yu } \\
\text { yan. }\end{array}$}} \\
\hline \multicolumn{2}{|c|}{$\begin{array}{l}\text { xiu shen, qi jia, zhi guo, ping tian xia } \\
\text { 修身, 齐家，治国，平天下 }\end{array}$} & & \\
\hline yi & 宜 & \multirow{3}{*}{\multicolumn{2}{|c|}{$\begin{array}{l}\text { 中也者, 天下之大本也; 和也 } \\
\text { 者, 天下之达道也。致中和, } \\
\text { 天地位焉, 万物育焉。 }\end{array}$}} \\
\hline yi & 义 & & \\
\hline i ren wei ji ren & 以仁 & & \\
\hline
\end{tabular}

